\title{
THE INFLUENCE OF WORKSHEET IMPLEMENTATION TOWARDS STUDENTS MATHEMATICS LEARNING OUTCOMES
}

\author{
Nurhidayah $^{1}$, Mimin Ninawati ${ }^{2}$, Slamet Soro ${ }^{3}$ \\ 1, 2,3 Pendidikan Guru Sekolah Dasar, Fakultas Keguruan dan Ilmu Pendidikan, Universitas \\ Muhammadiyah Prof. Dr. HAMKA, Indonesia \\ ${ }^{1}$ yayahnurhidayah19@gmail.com, ${ }^{2}$ mimin_ninawati@uhamka.ac.id, ${ }^{3}$ \\ slamet.soro@yahoo.co.id
}

Citation: Nurhidayah, Ninawati, M., \& Soro, S. (2020). The influence of worksheet implementation towards students mathematics learning outcomes. Indonesian Journal of Elementary Teachers Education, 1 (1), 49-56.

Received: 01-14-2020 Accepted: 05-31-2020 Published: 05-31-2020

\begin{abstract}
The purpose of this study was to examine the effect of worksheet implementation on students' mathematics learning outcomes. The participants of the study were fifth-grade students of SDN Kebon Pala 12 Pagi. The research was conducted in the second semester of the 2018/2019 academic year. The quantitative research method with a quasi-experimental design was conducted to answer the research question. The post-test only control group design was implemented in this experimental research. The data collected by multiple choices question developed by the researcher. The validity and reliability tests of the instrument were tested before the instrument administered to the participants. According to Biserial Point Correlation, there were 40 multiple choice questions with 30 valid questions and 10 drop questions. The reliability test using the KR-20 formula obtained $r$ calc $=1.033>r$ crit 0.361 $=r$ crit, then the data has a reliable instrument. Before the data analyzed in hypothesis testing, the normality test using the Liliefors were conducted to determine the normality of the data collected, the result shows that Lo $=0.0521<0.161=L t$, it can be concluded that the data is normally distributed. While the homogeneity test using the Fisher test obtained $F$ calc $=1.44<1.93=F$ crit, it can be concluded that the homogeneity testing obtained by the group variance data which is homogeneous distribution. The result of the hypothesis test used t-test proved that $t$ calc 10.169 with $t$ table 2.006 and $\alpha=0.05$, therefore the Ho is rejected which states that there is a significant influence of worksheet implementation on the students' learning outcomes.
\end{abstract}

Keywords: elementary student; student worksheets; mathematics learning outcomes. 


\section{INTRODUCTION}

Education for the life of humankind is an absolute necessity that must be fulfilled throughout life. According to Ninawati (2012), the era of globalization makes Indonesian people a part of the world community and also has implications for the economic sector, which at the same time has a close relationship with the field of education. Without education, it is impossible for a group of people to live thrive because education is a conscious and planned effort to create an atmosphere of learning and the learning process actively develops its potential to have religious, spiritual strength, self-control, personality, intelligence, noble character, and the skills needed by himself and the community. Education can also be interpreted as a conscious and systematic effort to achieve a standard of living or for better progress.

The school is an educational institution that aims to produce positive changes (behavior and attitudes) in students who are developing toward maturity. Learning in elementary schools is the basis for developing the potential of students to the next level so that stimuli are needed for existing competencies within students can develop properly (Puspita, Djatmika, \& Hasanah, 2016). Elementary school is the first formal level of education and has the responsibility of developing students' attitudes and skills. With the provision of a positive basis for knowledge, it will affect the quality of education better to the next level of education. It can be done through a paradigm shift in the learning process, namely changing the orientation of teacher-centered learning into student-centered learning. It is expected that a teacher becomes a facilitator to create a learning atmosphere that involves good interaction between teacher-student and student-student.

There is quite a lot of content that must be taught by elementary school teachers, one of them is Math. Given mathematics is very structured knowledge, e.g. mathematical skills must be built from previous skills. One of the basic abilities in learning mathematics is the ability of students to understand mathematics (Indriani et al, 2019). Mathematics is one of the education sciences that most often used in educational discipline and everyday life, and most students consider mathematics to be a subject that is difficult to learn and frightening. Moreover, mathematics lessons require high concentration so students can understand the material conveyed by the teacher well.

Based on the results of field observations on the activities of the fifth-grade Mathematics learning process at SDN Kebon Pala 12 Pagi in the second semester of the 2018/2019 academic school year showed the results of Mathematics learning that was very unsatisfactory. The results of evaluations conducted to 28 students who took part in the learning activities. There were still many students who get grades below the Minimum Mastery Criteria (KKM). While the KKM determined by SDN Kebon Pala 12 Pagi was 70. This proves that students' mathematics learning outcomes are low. In the learning process, students also lack enthusiasm and are bored to listen to the explanation from the teacher. Therefore student learning outcomes in mathematics are less than optimal. Student learning outcomes are not only referred to as knowledge but attitudes and skills also influence it. Thus, the assessment of student learning outcomes includes everything learned in school, both regarding knowledge, attitudes, and skills. This makes students more active, creative, and independent in the learning process so that it does not only emphasize the transfer of knowledge and memorization.

According to the problems mentioned in the previous paragraph, one solution is to provide teaching materials that are interesting, easy to understand but can enable students to learn more independently and develop their skills. The teaching material that meets these criteria is the Students Worksheet. According to Trianto (2009), the Students Worksheet is 
the student guide used to conduct investigations or problem-solving activities, its contain tasks that must be done by students. Therefore, Students Worksheet in learning can foster activities, creativity, independence, and provide opportunities for teachers to conduct individual guidance or group. Students Worksheet can help students obtain notes about the material learned through learning activities, so when students forget about learning can reopen the Students Worksheet.

Students' ability to understand mathematics will be able to make connections between their existing knowledge and new information that is applied in the context of everyday life. Students Worksheets who are good at learning mathematics will provide the widest opportunity for students so that they can develop their creativity in solving several problems (Arnilawati, Armiati \& Musdi, 2018). Students Worksheet can be said to be good if it is able to facilitate students to interact with the material provided. As one of the contents in school, mathematics is one of the most vital subjects and plays a strategic role in the development of science and technology, because learning mathematics is like training innovative patterns in solving problems faced. Though students should also be taught how to apply it in everyday life and not just the theoretical formulas. It aims to practice the creativity and ability of students to solve a mathematical problem.

The presentation of Students Worksheet can be developed with various innovations, such as combining Students Worksheet by giving assignments to conduct experiments or practicum. The good teaching materials must be able to help students to understand the material delivered by the teacher (Puspita, 2018). Practicum activities are needed in learning mathematics in the matter of Building Space so that students do not just memorize it. Each student has different abilities in solving mathematical problems. Because, it requires practice in critical thinking, creativity, and alternative. The obligation of the teachers to instill a sense of pleasure in the subject of mathematics by providing stimulation and encouragement for students to enjoy mathematics.

Based on the explanation above, the researcher use Student Worksheets given to students to develop students' learning habits into active and creative. The use of Student Worksheets given at school makes an influence on the Use of Student Worksheets on Mathematics Learning Outcomes at SDN Kebon Pala 12 Pagi.

\section{RESEARCH METHOD}

\section{Research Design}

This research was conducted in quantitative research methods. In this quantitative research, the research is in the form of numbers and the analysis is based on statistical calculations. The research method that will be used in this research is "Quasi Experiment". Experiments are looking for the influence of using Students Worksheet toward learning outcomes in mathematics. Experimental research is research that is intended to determine whether there is a result of "something" imposed on the subject of inquiry. In other words, experimental research tries to examine whether there is a causal relationship. The trick is to compare one or more experimental groups that were treated with one or more comparison groups that did not receive treatment.

The design implemented in this experimental research was Post Test Only Control Group Design. In this design, the samples taken both the experimental group and the control group were not chosen randomly. In conducting this study, the sample was divided into two groups, namely the experimental group with the use of Students Worksheet and the control group. The fifth-grade students of A Group were selected as the experimental group using the 
Students Worksheet, while The fifth-grade students of B group were selected as the control class.

This method is used to determine whether there is an influence on the use of Students Worksheet toward mathematics learning outcomes. This research was conducted on students of VA as the Experiment class and VB as the Control class. In the Experiment class using Students Worksheet while the Control class did not use Students Worksheet. At the end of the lesson, data collection is done through the Post-Test.

\section{Participant}

According to Maolani \& Cahyana (2015), the population is a generalization area consisting of objects/subjects that have certain qualities and characteristics determined by researchers to be studied and then drawn conclusions. The participants of this study were fifth-grade students of SDN Kebon Pala Pagi, East Jakarta, Indonesia. In this research, the participants consisting of 56 students which divided into two class; 28 students in VA and 28 students in VB. This research was conducted in the second semester of the 2018/2019 academic year, precisely in April to August 2019. The participants were selected by researchers using the Saturation Sampling Technique. Saturation sampling is a sampling technique if all populations are used as samples and also known as a census. This research includes saturation sampling from Nonprobability Sampling so that every element in the population does not have the same opportunity to be chosen as a sample, even the probability of certain members to be selected is unknown.

\section{Data Collection}

In this study, the data were collected by an objective test developed by the researcher. The test is in the form of a multiple-choice test consist of 30 items. An objective test is a technique or method used in carrying out measurement activities, there are various questions, statements, or a series of tasks that must be done or answered by students. In this study, students will be given a test at the end (post-test) in the form of multiple-choice with choices $\mathrm{a}, \mathrm{b}, \mathrm{c}$, and d of material about Build Space.

Before this test delivered to the participants, the validity and reliability test of the items will be tested first. This is done to determine whether the question is suitable for use as a test of learning outcomes or not.

\section{Data Analysis}

As the data collected in this research were quantitative data, the statistical test was conducted to analyze the data. The t-test was used to analyze the difference in students' learning outcomes between the experimental and control group. Before the data analyzed in a hypothetical test, the normality and homogeneity test was conducted to determine the normality and homogeneity of the data collected. The t-test was tested to answer the research question.

\section{RESULTS AND DISCUSSION}

\section{Comparison of Mathematics Learning Outcomes Data Description}

Comparison of classroom mathematics learning outcomes data using Students Worksheet and not using Students Worksheet can be seen from Table 1. Based on the table, it is seen that experimental class results obtained the highest value of 100 , the lowest value of 60 , the average (mean) of 87.53, the variances of 80.480, and the standard deviation of 8.971 . While the control class results obtained the highest value of 80 , the lowest value of 47 , the 
average (mean) of 60.61 , the variances of 116.331 , and the standard deviation of 10.785 . Comparison of these data proved that any influence of mathematics learning outcomes between the experimental and control class.

Table 1. Comparison of Mathematics Learning Outcomes Data

\begin{tabular}{lll}
\hline Data Results & Experiment & Control \\
\hline Lowest Value & 60 & 47 \\
Highest Value & 100 & 80 \\
Average & 87.53 & 60.61 \\
Variance & 80.480 & 116.321 \\
Standard Deviation & 8.971 & 10.785 \\
\hline
\end{tabular}

\section{Validity Test}

A validity test is very important in research because to find out whether a question is valid or not. The results of the study are valid if there are similarities between the data collected and the data that actually occurs on the object under study. In this study, the formula used to find the validity coefficient was the biserial point formula. The validity test was conducted at SDN Kebon Pala 12 Pagi with the number of students as many as 30 people and the number of question instruments as many as 50 items. The questions are arranged based on the appropriate indicators in the mathematics subject for fifth-grade about Build Space.

This research consists of multiple-choice questions with four choices of answers, namely a, b, c, and d. The researcher used biserial point correlation because if the answer is correct it gets a value of 1 , and if the answer is wrong it gets a value of 0 . Based on the calculation, the calculated coefficient value of each item is obtained. Then to determine whether the problem is valid or not, the value of the biserial point correlation coefficient is compared with the value of the biserial point $r$ correlation with $n=30$ at a $5 \%$ significance level of 0.361 . The provisions in each item counted to be valid are $r$ calc $>r$ table.

Table 2. Classification of Test Items for Mathematics Learning Outcomes Test Instruments

\begin{tabular}{lll}
\hline Classification & Number of Items & Number of Item \\
\hline \multirow{2}{*}{ Valid } & \multirow{2}{*}{30} & $1,2,3,4,5,7,8,10,11,12,13,14,15,17,18,19$, \\
& & $22,23,24,25,26,27,28,29,30,31,33,37,39$, \\
Not Valid & 10 & 40 \\
\hline
\end{tabular}

\section{Reliability Test}

After the validity test was done, researchers carried out the reliability test. Reliability shows an understanding of the measurement results, whether it is still consistent if measurements are tested twice or more of the same symptoms using the same measuring device. So, an instrument can be trusted enough as a data collection tool because the instrument is already good.

In this study, the reliability formula used was KR-20. This is caused by the evaluation tools used are a multiple-choice objective test. Reliability serves as a measuring tool that describes the accuracy of the test participants when answers the questions. The instrument is said to be reliable when $\mathrm{r}$ calc $>\mathrm{r}$ table. After calculating using the K-R 20 formula, the calculated value is obtained as follows: Instrument reliability of 30 students obtained a count of 1.033 when compared with an $r$ table of 0.361 then $r$ calc $>r$ table and it can be concluded that the test was declared to be reliable and fit for use as an assessment instrument. 
Table 3. Reliability Test Results

\begin{tabular}{lll}
\hline Value $\mathbf{r}_{\text {calc }}$ & Value $\mathbf{r}_{\text {table }}$ & Description \\
\hline $\mathbf{1 . 0 3 3}$ & $\alpha=0.05$ & $\mathrm{r}_{\text {calc }}>\mathrm{r}_{\text {table }}$ \\
& 0.361 & Reliable Instrument \\
\hline
\end{tabular}

\section{Normality Test}

Normality testing is carried out using the Liliefors Test. Data is normally distributed if Lo $\leq \mathrm{Lt}$. Normality test is used to find out whether the data is normal or not. A normality test is a prerequisite before carrying out a homogeneity test. So it can be concluded that the data must be normally distributed first before the homogeneity of data can be calculated. The results of normality test calculations can be seen in Table 4.

Table 4. Normality Test Results

\begin{tabular}{lllll}
\hline Class & $\mathbf{N}$ & $\mathbf{L}_{\text {calc }}$ & $\mathbf{L}_{\text {table }}$ & Description \\
\hline Exsperiment & 28 & 0.1112 & 0.1610 & $\mathrm{~L}_{\mathrm{o}}<\mathrm{L}_{\mathrm{t}}$ \\
Control & 28 & 0.1540 & 0.1610 & $\begin{array}{l}\text { Data is normally } \\
\text { distributed }\end{array}$ \\
\hline
\end{tabular}

\section{Homogeneity Test}

Homogeneity test in this study used the Fisher formula with several criteria, namely:

If $\mathrm{F}$ calc $<\mathrm{F}$ table, then both data are homogeneous.

If $\mathrm{F}$ calc $\geq \mathrm{F}$ table, then both data are not homogeneous.

From the calculation results obtained $\mathrm{F}$ calc $=1.445$ and $\mathrm{F}$ table $=1.930$ so $\mathrm{F}$ calc $<\mathrm{F}$ table is $1.445<1.930$ of significance $\alpha=0.05$. Homogeneity test results can be seen in the following Table 5. Based on the results of calculations performed by Fisher's formula in the experimental class using the Students Worksheet and the control class by not using the Students Worksheet showed the F calc is smaller than F table. From the calculation results can be obtained the value of $F$ calc $=1.445$ with a variance of 80.480 and 116.332 , the value of $\mathrm{F}$ table $=1.930$ at the significance level $\alpha=0.05$ with the numerator $\mathrm{df}=27$ and the denominator $\mathrm{df}=27$. Because $\mathrm{F}$ calc $<\mathrm{F}$ table is $1.445<1.930$ can be concluded that both the experimental and control class have the same or homogeneous variance conditions.

Table 5. Homogeneity Test Results

\begin{tabular}{llllll}
\hline Class & $\mathbf{N}$ & Variance & $\mathbf{F}_{\text {calc }}$ & $\mathbf{F}_{\text {table }}$ & Description \\
\hline Exsperiment & 28 & 80.480 & 1.445 & 1.930 & $\mathrm{~F}_{\text {calc }}<\mathrm{F}_{\text {table }}$ \\
Control & 28 & 116.321 & & & Homogeneous Sample Data \\
\hline
\end{tabular}

\section{Hypothesis Test}

To test the t-test hypothesis using the two-tailed with a significant level $=0.05$, namely by testing the two mean paired data. From the calculation of hypothesis testing with ttest at a significant level $\alpha=0.05$ with $\mathrm{df}=56-2=54$ for 2.006 because $\mathrm{t}$ calc is greater than t table $(10.169>2.006)$, it can be concluded that $\mathrm{H} 1$ is accepted and $\mathrm{H} 0$ is rejected, which means there is a significant influence of the use of Students Worksheet on the learning outcomes of students in fifth-grade at SDN Kebon Pala 12 Pagi.

Table 6. Hypothesis Test Results

\begin{tabular}{lllllll}
\hline Group & $\mathbf{N}$ & $\mathbf{d f}$ & $\mathbf{t}_{\text {calc }}$ & $\mathbf{t}_{\text {table }}$ & Criteria & Conclusion \\
\hline Exsperiment Class & 28 & 54 & 10.169 & 2.006 & $\mathrm{t}_{\text {calc }}>\mathrm{t}_{\text {table }}$ & Reject $\mathrm{H}_{\mathrm{o}}$ \\
Control Class & 28 & & & & & \\
\hline
\end{tabular}


Based on the results of the study above, Students Worksheet can affect student mathematics learning outcomes. According to Khairunnisa, Rizkiana, \& Apriani (2019), the use of Students Worksheet of photosynthesis material can improve student learning outcomes as has been shown the results of the $\mathrm{N}$-gain score of the experimental class is higher than the control class. The use of Students Worksheet is able to improve student learning outcomes because Students Worksheet is able to assist students in understanding Mathematical concepts and materials taught by teachers. While Riswanto (2015), the tendency of mathematics learning outcomes of students who use the Students Worksheet is more useful and has a positive effect on student achievement. Learning with Students Worksheet will facilitate the power of understanding concepts and if students already understand the concept of the lesson, the development materials will be easy and fun to learn.

\section{CONCLUSION AND RECOMMENDATION}

Referring to the data and information obtained during conducting research can be concluded as follows: (1) Calculation of mathematics learning outcomes for class VA as a class that uses Students Worksheet has an average value of 87.53; (2) Calculation of learning outcomes in class VB mathematics as a class that does not use Students Worksheet has an average value of 60.61 .

In the inferential statistical test, the t-test, the results of the hypothesis test show that $\mathrm{t}$ calc $10.169>2.006 \mathrm{t}$ table, based on the criteria for rejecting Ho and H1 testing. Thus it can be concluded that there is an influence, in the sense that the Use of Students Worksheet influences the learning outcomes of students in subjects at SDN Kebon Pala 12 Pagi.

Researchers realize this research is far from perfect, because of the limitations of the knowledge they have and many other factors that can determine the success of this research. Based on the results obtained, it can be suggested as follows: (1) It is expected that teachers in teaching mathematics can use teaching materials in learning that will be better targeted well for students. For example, learning mathematics using learning methods that attract students to play an active role in the learning process so that it makes it easier for students to remember ongoing science inputs. Thus, the use of good methods will have an impact on learning interest; (2) Researchers are expected to take into account the exact time of each research step in learning to use Students Worksheet so that the research goes as planned. 


\section{REFERENCES}

Arnilawati, Armiati, \& Musdi, E. (2018). Students' worksheet validity based on contextual teaching and learning in junior high school. International Conferences on Educational, Social Sciences and Technology, 496-500. https://doi.org/10.29210/2018172

Indriani, R., Puspita, A. M. I., Ninawati, M., Handayani, H., \& Agusfianuddin. (2019). Contextual teaching and learning untuk meningkatkan kemampuan pemahaman konsep pecahan. KALAMATIKA: Jurnal Pendidikan Matematika, 4 (1), 109-116.

Khairunnisa, Y., Rizkiana, F., \& Apriani, H. (2019). Pengaruh penggunaan lembar kerja peserta didik (lkpd) tematik pada materi fotosintesis terhadap motivasi, kemandirian, dan hasil belajar. QUANTUM: Jurnal Inovasi Pendidikan Sains, 10 (2), 121-129.

Maolani, R. A., \& Cahyana, U. (2015). Metodologi penelitian pendidikan. Jakarta: Rajawali Pers.

Ninawati, M. (2012). Kajian dampak bilingual terhadap perkembangan kognitif anak sekolah dasar. Jurnal Ilmiah Widya, 29 (324), 23-27.

Puspita. A. M. I. (2018). Pengaruh penerapan pendekatan kontekstual terhadap aktivitas dan hasil belajar siswa di SDN I Campurdarat. Jurnal Dewantara, 4 (1), 33-45.

Puspita, A. M. I., Djatmika, E. T., \& Hasanah, M. (2016). Peningkatan hasil belajar siswa berbantuan buku teks berbasis kontekstual untuk siswa kelas II sekolah dasar. Jurnal Pendidikan: Teori, Penelitian, dan Pengembangan, 1 (10), 1880-1883.

Riswanto, E. (2015). Pengaruh penggunaan lembar kerja siswa terhadap prestasi belajar matematika siswa kelas III SDN Kotagede 3 Yogyakarta tahun pelajaran 2014/2015. Trihayu: Jurnal Pendidikan Ke-SD-an, 2 (1), 233-236.

Trianto. (2009). Mendesain model pembelajaran inovatif, progresif, dan kontekstual. Jakarta: Kencana Prenada. 